\title{
Needham at the crossroads: history, politics and international science in wartime China (1942-1946)
}

\author{
THOMAS MOUGEY*
}

\begin{abstract}
In 1946, the British biochemist Joseph Needham returned from a four-year stay in China. Needham scholars have considered this visit as a revelatory period that paved the way for his famous book series Science and Civilization in China (SCC). Surprisingly, however, Needham's actual time in China has remained largely unstudied over the last seventy years. As director of the Sino-British Scientific Cooperation Office, Needham travelled throughout Free China to promote cooperation between British and Chinese scientists to contain the Japanese invasion during the Second World War. By rediscovering Needham's peregrinations, this paper re-examines the origins of his fascination for China. First, it contests the widely held idea that this Chinese episode is quite separate and different from Needham's first half-life as a leftist scientist. Second, it demonstrates how the political and philosophical commitments he inherited from the social relations of science movement, and his biochemical research, shaped his interest in China's past. Finally, this paper recounts these forgotten years to reveal their implications for his later pursuits as historian of science and as director of the natural-science division of UNESCO. It highlights how, while in China, Needham coconstituted the philosophical tenets of his scientific programme at UNESCO and the conceptual foundations of his SCC.
\end{abstract}

\section{Introduction}

In March of 1943, the British biochemist Joseph Needham arrived in Chongqing, the still-standing capital of war-torn China, to establish the Sino-British Science Cooperation Office (SBSCO). As SBSCO director, Needham organized bilateral cooperation between British and Chinese scientists in order to contain Japan's imperial expansion in continental Asia. During the four years of his tenure, Needham travelled all over Free China, visiting hundreds of research facilities and travelling over 25,000 kilometres. Each visit consisted of a mixture of tasks ranging from monitoring the infrastructural state of China's research facilities, to delivering material, equipment and literature, to lecturing about SBSCO's mission. Alongside his diplomatic and scientific duties, Needham began first-hand exploration of China's ancient scientific traditions.

Global historians of science and Needham specialists have generally considered Needham's Chinese interlude to be a revelatory experience, sparking his lifelong

\footnotetext{
* Maastricht University Faculty of Arts and Social Sciences, PO Box 616, 6200 MD Maastricht, the Netherlands. E-mail: t.mougey@maastrichtuniversity.nl.

I would like to thank archivists at UNESCO, Paris and Cambridge University Library for their assistance in accessing key records. I am also grateful to Geert Somsen, Raf de Bont and Wiebe Bijker for their constructive comments on earlier drafts of this manuscript.
} 
fascination with China and forming the epistemological foundations of his famous book series Science and Civilization in China (SCC). In China, they have argued, Needham came to grips with his Grand Question: 'why is it that the modern experimental and theoretical system of science arose not in China, but in Western Europe?' Such interests would eventually lead him to give up biochemistry to become a full-time historian of science. ${ }^{1}$

Surprisingly, however, Needham's actual experience in China has remained largely unstudied. ${ }^{2}$ The existing literature, which will be reviewed in the first section, has generally disregarded the extensive personal papers and correspondence that Needham kept during the four years of his mission. Instead, Needham scholars have explored his initial interest in China as it was documented in later reflections that Needham produced following the publication of SCC in 1954. They have regarded his research on China retrospectively, on the basis of the importance Needham gave to it at the turn of the 1960s. By that time, Needham was trying to strengthen the historiographical value of studying Chinese science and to establish his authority as a historian. As part of this agenda, he produced several reflective pieces, such as The Grand Titration, where he reduced his first encounter with China to a historiographical eye-opener. ${ }^{3}$ Based on these later accounts, Needham scholars have tended to reinforce this narrative by framing his time in China as a founding experience in the formulation of his Grand Question and his emergence as a pioneering global historian of science. ${ }^{4}$

This approach has several consequences. Besides keeping a veil over four crucial years in Needham's political and scientific trajectory, Needham scholars have separated his interest in China from his so-called 'first half-life' as a biochemist, a member of the leftist social relations of science (SRS) movement, and a scientific diplomat in wartime China. ${ }^{5}$ In addition, their emphasis on SCC has led to a disregard for what Needham actually did in

1 Joseph Needham, 'Abstract of a lecture on science and civilization in China', October 1944, Needham Papers, Cambridge University Library, Cambridge (subsequently NP), Folder C.73; Kenneth Boulding, 'Great laws of change', in Anthony M. Tang, Fred M. Westfield and James S. Worley (eds.), Evolution, Welfare and Time in Economics, Lexington, MA: Lexington Books, 1976, p. 9.

2 Only Simon Winchester, and Maurice Goldsmith to a lesser extent, have produced detailed descriptive accounts of Needham's time in China. Both focused on his expeditions to discover ancient China rather than on his SBSCO mission. See Simon Winchester, Bomb, Book, and Compass: Joseph Needham and the Great Secrets of China, London: Penguin Books, 2008; Maurice Goldsmith, Joseph Needham: 20th-Century Renaissance Man, Paris: UNESCO Publishing, 1995, pp. 69-88.

3 Joseph Needham, The Grand Titration: Science and Society in East and West, London: Allen and Unwin, 1969.

4 Mikulas Teich and Robert Young (eds.), Changing Perspectives in the History of Science: Essays in Honour of Joseph Needham, London: Heinemann, 1973; Irfan Habib and Raina Dhruv (eds.), Situating the History of Science: Dialogues with Joseph Needham, New Delhi: Oxford University Press, 1999; Morris F. Low, 'Introduction to beyond Joseph Needham: science, technology, and medicine in East and Southeast Asia', Osiris (1998) 13, pp. 1-8; Francesca Bray, 'Joseph Needham, 9 December 1900-24 March 1995', Isis (1996) 87, pp. 312-317; Mark Elvin, 'Symposium: the work of Joseph Needham', Past and Present (1980) 87, pp. 17-20; Xi Xu, 'British left-wing writers and China: Harold Laski, W.H. Auden and Joseph Needham', Hong Kong: University of Hong Kong, unpublished, 2013.

$5 \mathrm{Lu}$ Gwei-Djen first introduced the expression 'first half-life' to refer to Needham's life as a Cambridge biochemist prior to his discovery of China in 'The first half-life of Joseph Needham', in Li Guohao, Zhang Mengwen and Cao Tianqi (eds.), Explorations in the History of Science and Technology in China, Shanghai: Shanghai Classics Publishing House, 1982, pp. 1-38. 
Chongqing and how he processed his new experiences. Travelling through China, Needham was struck by its state of disarray, by its 'grinding poverty' and by his local colleagues' distress at the chronic lack of facilities since the Japanese invasion. ${ }^{6}$ At the same time, he became impressed by the country's grandiose past, and cultivated the conviction that because of its scientific heritage ('the technical excellence and competence of Chinese scientific and industrial workers'), and its forthcoming socialist transformation, China would become the future political and scientific front line for all humankind. ${ }^{7}$

In this paper, I will lift the curtain from Needham's wartime experience and examine the emergence of his fascination for China as a product of his time at the SBSCO and in relation to his pre-war world view. To retrieve the breadth of Needham's experience, I will draw largely on the rich collection of SBSCO papers and correspondence compiled in his personal archive at Cambridge University Library. ${ }^{8}$ In the following, I will first offer a review of the existing literature on Needham and contest the widely held idea that Needham's time in China was separate and different from his first half-life. I will then resituate Needham's interest in China in relation to his political and intellectual trajectory during the 1930s, demonstrating how the political, historical and philosophical commitments Needham inherited from the SRS movement played an essential role in shaping his interest in China's past. In the second half of the article, I will recount his crucial, yet forgotten, Chinese experience. Using his book Science Outpost and his private papers, I will shed light on the politics of his mission and its implications for Needham's later pursuits. I will show how, in exploring ancient Chinese science while helping Free China's stranded scientific communities, Needham formulated the tenets of his later internationalist commitments at UNESCO. At the same time, as I shall demonstrate, these experiences provided him with the conceptual foundations of his SCC. ${ }^{9}$ This paper will therefore bridge the gap between Needham's first and second 'halflives' and fill the historiographical lacuna of his time in wartime China.

\section{The invisible experience}

There is a substantial literature on how Needham apprehended China and on the historiographical origins of his Science and Civilization in China. This body of work can be divided into two subgroups.

6 Joseph Needham, 'Letters I: excerpts from letters, February, 1943, to December, 1943', in Joseph Needham and Dorothy Needham, Science Outpost: Papers of the Sino-British Science Co-operation Office (British Council Scientific Office in China) 1942-1946, London: The Pilot Press Ltd, 1948, pp. 27-49, 48; Needham, 'Memoranda on Future British Council policy in China', NP, Folder C.95, p. 36.

7 Joseph Needham, 'Article VII: the Chungking Industrial and Mining Exhibition (1944)', in Needham and Needham, op. cit. (6), pp. 189-194, 194.

8 The relevant material can be found in the Needham Papers, GB 12, Cambridge University Library, Section C: Sino-British Science Cooperation Office, Folders C1-C166, as well as parts of Section D: United Nations Educational, Scientific and Cultural Organization (UNESCO), Folders D1-D365.

9 Gail Archibald brushed upon Needham's time in China and its role with respect to UNESCO in 'How the " $S$ " came to be in UNESCO', in Patrick Petitjean, Vladimir Zharov, Gisbert Glaser, Jacques Richardson, Bruno de Padirac and Gail Archibald, Sixty Years of Science at UNESCO 1945-2005, Paris: UNESCO Publishing, 2006, pp. 29-34. 
The first subgroup focuses on historicizing and critically analysing SCC's non-dualistic epistemology, the relational view that modern science is an ecumenical enterprise rooted in cultural, scientific and technological interchanges between East and West. Historians such as Gregory Blue and Shiv Visvanathan have seen this relationalism as the main grounds of SCC's uniqueness. ${ }^{10}$ To understand this epistemological egalitarianism, both scholars have plunged into the 1930 s origins of Needham's synthetic mindset. ${ }^{11}$ Blue, for instance, has shown that Needham recognized as early as the 1920s the validity of different moulds of experience, such as religion and science, for understanding nature and society, which he eventually synthesized into a unitary epistemology through his SCC. Other scholars have reinforced this emphasis on Needham's mindset by characterizing his search for a relational and anti-dualist outlook as an essential factor eliciting his interest in China and its non-dualist Taoist philosophy. ${ }^{12}$ This tendency is particularly visible in the work of Nathan Sivin and Liu Dum. Both have contrasted Needham's epistemology against the Western-centred perspectives that prevailed in the global histories of science, sinological studies and civilizational history of the time. ${ }^{13}$

Only a handful of scholars - the second subgroup - has investigated Needham's interest in China (and his SCC) in light of his Marxist leanings. ${ }^{14}$ Among these, Gregory Blue and Timothy Brooke have acknowledged that Needham's Chinese scholarship would be ungraspable without his Marxism and have highlighted the mark it made on his historical perspective. At the same time, their point has been to play down Marxism's grip on Needham's Chinese investigations, reducing it to a mere epistemological tool. They have portrayed it as of a singular and highly heterodox kind. Brooke and Blue have particularly highlighted Needham's free use of official Marxist categorization to analyse Chinese society, notably employing the notions of an 'Asiatic mode of production', 'Asiatic bureaucratism', and 'bureaucratic feudalism', which the official Stalinist historiography had expelled from its vocabulary in the 1930s. For Brooke, Needham's

10 Low, op. cit. (4); Aant Elzinga, 'Revisiting the "Needham paradox"', in Habib and Dhruv, op. cit. (4), pp. 73-113; Nathan Sivin, Science in Ancient China: Researches and Reflections, Brookfield, VT: Ashgate Publishing Company, 1995; Roger Hart, 'Beyond science and civilization: a post-Needham critique', East Asian Science, Technology and Medicine (1999) 16, pp. 88-114; Nathan Sivin, 'Why the scientific revolution did not take place in China - or didn't it?', in Li, Zhang and Cao, op. cit. (5) pp. 89-106.

11 Gregory Blue, 'Science(s), civilization(s), historie(s): a continuing dialogue with Joseph Needham', in Habib and Dhruv, op. cit. (4), pp. 29-72. See also Timothy Brook, 'The sinology of Joseph Needham', Modern China (1996) 22, pp. 340-348.

12 See, for instance, Shiv Visvanathan, 'The strange quest of Joseph Needham', in Habib and Dhruv, op. cit. (4), pp. 198-219.

13 Nathan Sivin, 'Max Weber, Joseph Needham, Benjamin Nelson: the question of Chinese science', in Eugene V. Walter, Vytautas Kavolis, Edmund Leites and Marie Coleman Nelson (eds.), Civilization East and West: A Memorial Volume for Benjamin Nelson, Atlantic Highlands, NJ: Humanities Press, 1985, pp. 37-49; Liu Dum, 'A new survey of the "Needham Question”', Studies in the History of Natural Sciences (2000) 19, pp. 293-305. On civilization see Diederick Raven, 'Needham, science and Chinese civilisation', unpublished, at www.academia.edu/1429134/Needham_Science_and_Chinese_Civilisation, accessed 30 November 2014.

14 Gregory Blue, 'Joseph Needham, heterodox Marxism and the social background to Chinese science', Science and Society (1998) 62, pp. 195-217; Brook, op. cit. (11); Timothy Brook and Gregory Blue, China and Historical Capitalism: Genealogies of Sinological Knowledge, Cambridge: Cambridge University Press, 1999; Xu, op. cit. (4). 
interchangeable use of this terminology denotes his heterodox usage of the Marxist analytical system, while for Blue, Needham's unorthodoxy invalidates the anti-Marxist critique that his SCC received in the 1950s.

In spite of valuable insights into SCC's historiographical and epistemological origins, the literature suffers some significant limitations when it comes to understanding Needham's fascination with China. First, Needham scholars have investigated Needham's interest in China strictly for the purpose of gaining a deeper understanding of SCC. In a way, Needham's China has been essentially explored as a literary and epistemological object rather than as a lived experience, which may explain the general disregard for his actual activities in China during the war.

A second problem emerges as well. The bulk of existing scholarship has investigated the pre-war foundations of Needham's outlook on China from the point of view of his post-war intellectual trajectory rather than that of his actual pre-war posture. This is particularly striking in the works of Blue and Brooke. Both have used as a reference point for their study not the radical Marxist framework that permeated Needham's view before and in China, but the milder Marxist principles that Needham adopted in the 1950s and 1960s. In the late 1950s, Needham faced a fierce anti-Marxist opprobrium that major historians of China like Karl Wittfogel heaped on the first volumes of SCC. ${ }^{15}$ Following this episode, Needham trivialized the significance of Marxism in his work. He reduced it to a mere historiographical instrument that aided him to formulate an alternative to the conventional 'internalist' approach to the history of science. So while Blue and Brooke have recognized the relevance of Needham's first half-life for the making of his SCC by highlighting the Marxism in his approach, they have underestimated its importance by using Needham's milder post-war Marxism as their frame of reference rather than the more radical pre-war version that actually permeated his investigations of China during the war.

The same goes for Needham's anti-dualism. In response to his critics, Needham gradually softened the Marxist epistemology that originally guided his investigations into the origins of modern science. By the 1960s, he instead sublimated his synthetic approach in his attempt to explain modern science as the conciliation of the cultures of Asia and the West. This refashioning, which he articulated in Within the Four Seas (1969) and History and Human Values (1975), has misled Needham scholars who have dug into his first half-life to grasp his interest in China. ${ }^{16}$ Needham's later bridge-building outlook is in fact much less relevant for explicating his original motivation to study China. First of all, this is because Needham's world view in the 1930s, though relational, was far from resembling the integrated and humanistic philosophy he adopted in the 1960s. Upon his departure to China, his world view, though impregnated with religious considerations, was based upon a faith in the combined transformative power of science

15 On the anti-Marxist critiques of Needham's Science and Civilization in China see Charles C. Gillespie, 'Perspectives (essay review of J. Needham, Science and Civilization in China, Vol. 1 \& 2)', American Scientist (1957), pp. 169-176; Karl Wittfogel, 'Review of Joseph Needham, Science and Civilisation in China, Vol. 2', American Anthropologist (1958) 60, pp. 398-400.

16 Joseph Needham, Within the Four Seas, London: Allen \& Unwin, 1969; Needham, 'History and human values: a Chinese perspective for world science and technology', Centennial Review (1976) 20, pp. 1-35. 
and Marxism. ${ }^{17}$ Second, and more important, historians' intellectualist emphasis overlooks the fact that, in the 1930s and the 1940s, Needham primarily shaped and subordinated his scientific investigations to the advancement of radical social change, which he expected in England and foresaw in wartime China. ${ }^{18}$

Hence the bulk of the existing literature not only disregards how Needham discovered China during the war, but also studies his interest in China based on inadequate epistemological considerations. Looking at SCC retrospectively, this scholarship has ultimately been built upon a flawed conception of Needham's pre-war trajectory inherited from the epistemological and ontological reorientation he adopted in the 1960s and the 1970s. This has the effect of removing his first half-life, and more surprisingly his voyage in China during the Second World War, from our understanding of his relation to China. The relationships that these scholars had with Needham may explain their somewhat uncritical acceptance of his 1960s epistemological reorientation. Most of them were former students and close collaborators of Needham on his multi-decennial SCC. This closeness rendered the task of critically appraising Needham's work all the more challenging, since for most of them his legacy became theirs. As Mark Elvin noticed thirty-five years ago:

There is a special difficulty in evaluating Needham's work, which must be faced honestly. Almost every living scholar who is qualified in science and sinology has been drawn, for entirely proper and praiseworthy reasons, into the web of collaborative endeavour that surrounds Science and Civilisation in China. There are almost no outsiders in this still small field who could be insiders, and it is hard for those inside the enterprise to look at it with an outsider's objectivity. ${ }^{19}$

The following sections put the spotlight on Needham's wartime Chinese experience and reveal it to be a decisive moment in the formulation of some of the core concepts of his SCC. They also suggest that China appealed to Needham not only historically, but also politically and scientifically. Retrieving his multifaceted interests in China will finally allow me to show how closely his concerns for Chinese science were connected to his interests in international reorganization that led to his involvement in UNESCO after the war. At the same time, his fascination with China was not without its roots either, and in order to understand these, I will first introduce the main tenets of his world view prior to his departure for Chongqing.

17 This nexus was studied Gary Werskey in The Visible College: A Collective Biography of British Scientists and Socialists of the 1930s, 2nd edn, London: Free Association Books, 1988; and by William McGucken in Scientists, Society, and State: The Social Relations of Science Movement in Great Britain 1931-1947, Columbus: Ohio State University Press, 1984.

18 On Needham's political hopes for Britain see Joseph Needham, 'History is on our side: address to clergy (1937)', in Needham, History Is on Our Side: A Contribution to Political Religion and Scientific Faith, London: George Allen \& Unwin Limited, 1946, pp. 22-34; on his hopes for China see, for instance, Joseph Needham to H.D. Liem, 22 March 1941, NP, Folder C7.

19 Elvin, op. cit. (4), pp. 19-20. 


\section{Needham and China in the 1930s}

Well before his appointment at the SBSCO, Needham was already intrigued by China's history and politics. Needham recalled in The Grand Titration that he had first formed the idea 'of writing a systematic, objective and authoritative treatise on the history of science, scientific thought and technology in the Chinese culture-area' around 1938. ${ }^{20}$ And by the time of his departure, he saw in the growing Chinese communist front the dawn of a 'new trend towards collectivism and socialism worldwide'. ${ }^{21}$ Needham's political and historical fascinations with China were connected through his involvement in the so-called scientific left and in the scientistic forms of historical materialism developed in this movement in the 1930s. Its most dominant theoretician, no doubt, was J.D. Bernal, and his views on science and historical development caught most attention, especially through his book The Social Function of Science. ${ }^{22}$ But Needham developed his own theory of scientific and social development that distinguished itself from Bernal's by a humanist scepticism toward scientism and an evolutionary approach to the coadvancement of science and politics, founded in his embryology.

Needham came to see the world embracing 'the giant vista of evolution'. ${ }^{23}$ Drawing from contemporary research in the natural and social sciences, Needham envisioned nature as a unified whole with humankind as its crown. ${ }^{24}$ Nature was not static, but in motion through evolution, which he saw as 'the passage from simplicity to complexity ... from low to high organization'. ${ }^{25}$ Convinced of the universality of evolution, Needham regarded this evolutionary process as an entry point that penetrated all spheres of life, including human social life. 'We must think of sociological development', he postulated, 'as continuous with biological. History is the continuation of Natural History'. ${ }^{26}$ Needham's reading of social evolution resonated very much with the teleological and deterministic interpretation Herbert Spencer had given fifty years earlier in his system of synthetic philosophy. ${ }^{27}$ Yet the mechanism of change differed between the

20 Needham, op. cit. (3), p. 190.

21 Joseph Needham to Liem, H.D., 22 March 1941, NP, folder C7.

22 John Desmond Bernal, The Social Function of Science, London: George Routledge \& Sons Ltd, 1939.

23 Joseph Needham, 'Integrative levels: a revaluation of the idea of progress (Herbert Spencer Lecture at Oxford University, 1937)', in Needham, Time: The Refreshing River (Essays and Addresses, 1932-1942), London: George Allen and Unwin Ltd, 1943, pp. 233-272, 258.

24 On embryological research in the 1930s and Needham's own chemical embryology see Jean-Claude Dupont, 'Joseph Needham (1900-1995) et l'embryologie chimique', in Patrick Petitjean, Stéphane Schmitt and Catherine Jami (eds.), Science, histoire et politique: L'exemple de Cambridge, Paris: Magnart-Vuibert, 2009, pp. 65-80; Danièle Ghesquier, 'Le concept de protoplasme chez Needham', in ibid., pp. 81-97; Pnina G. Abir-Am, 'The philosophical background of Joseph Needham's work in chemical embryology', in Scott F. Gilbert (ed.), Developmental Biology: A Comprehensive Synthesis, vol. 7: A Conceptual History of Modern Embryology, New York and London: Plenum Press, 1991, pp. 159-180.

25 Joseph Needham, 'The gist of evolution (1931)', in Needham, op. cit. (18), pp. 121-145, 121.

26 Joseph Needham, 'History is on our side', op. cit. (18), p. 24.

27 Herbert Spencer, Principles of Sociology, London and Edinburgh: Williams and Norgate, 1876; Spencer, Principles of Biology, London, Edinburgh and Oxford: Williams and Norgate, 1898; Spencer, First Principles, 6th edn, London: Williams and Norgate, 1900. 
two: where Spencer valued competition, Needham identified its opposite - cooperation between people - as 'the necessary foundation to a higher order of human society'. ${ }^{28}$

Needham conceived of cooperation - e.g. between cells, organisms and ultimately human beings - as the triggering mechanism behind evolutionary change, and science as its indicator. Consequently, Needham considered that a full scientific understanding of mankind's evolutionary course should enable the scientist to confidently affirm, contra Spencer, that 'the [capitalist] state in which we know [society] today was not, to a very high degree of probability, its final state'. ${ }^{29}$ For Needham science was not just an innocent and passive mirror of nature's evolutionary march. It constituted a powerful political compass that could guide the transcendence of capitalism towards evolutionary, sound socialism. This belief led him to affirm in 1937, in the face of the fascist threat, that the world faced a choice between fascist-capitalist decay and the advancement towards socialism: between contradicting nature's evolutionary rules and embracing them to move on to the political and biological harmony of a collectivist society. ${ }^{30}$

Needham therefore subscribed to the idea that science, understood as an intellectual endeavour, was nature's mirror and as such part of nature's realm. But he, with his socialist-minded comrades, did not ignore what they considered to be all the more true of science: the fact that as a social institution, science and its representatives 'did not live in a vacuum [and were] conditioned by the structure of the world they lived in'. ${ }^{31}$ Needham believed that enacting science's essential values would increase its growth and transformative power; he feared that their negation could lead to science's demise. In his Carmalt Lecture at Yale University, Needham explained that science depended on material and cultural conditions, and for this reason one 'must not dissociate scientific advances from the technical needs and processes of the time, and the economic structure in which all are embedded'. ${ }^{32}$ For him, science was not eternal. It could rise and fall depending on the state of human affairs.

Studying the historical development of science, Needham observed that science functioned differently depending on whether it evolved in a fascist, capitalist, soviet or collectivist organization of society. In unison with his leftist comrades, Needham concluded that science could be either pure or impure, growing or dying, constructive or destructive, depending on the context of its elaboration and use. Yet, unlike other leftist scientists, Needham composed a distinct evolutionary typology where fascist and capitalist regimes lay at the foot of the ladder as degenerated social orders oppressive of science, while Marxist collectivism stood at its top as 'the only theory that could guarantee that science would be used for the benefit of mankind'. ${ }^{33}$ While Needham understood science as having immense explanatory and transformative power, he depicted it nonetheless as an alarmingly fragile entity likely to be swayed by unreasoned

28 Needham, op. cit. (18), p. 260.

29 Needham, op. cit. (18), p. 22.

30 Needham, op. cit. (18).

31 Joseph Needham, 'Limiting factors in the history of science observed in the history of embryology (Carmalt Lecture at Yale University, 1935)', in Needham, op. cit. (23), pp. 141-159, 145.

32 Needham, op. cit. (31), p. 144.

33 Joseph Needham, 'Rough notes for lecture biology and Marxism', c.1930s, NP, Folder G57. 
societal choices. Needham perceived science as a clay-footed giant: powerful enough to transform society, and yet so frail as to perish in an instant. In the face of the growing fascist threat, Needham regarded the growth of science less as a self-propelled and eternal enterprise than as a political project tied to, and dependent upon, society's destiny. This conception of science not only motivated his political militancy in Britain; it also permeated his first contacts with China in the late 1930s, which, as we shall see, revolved around helping Chinese scientists and understanding the mysterious stoppage of Chinese science in the Middle Ages.

Needham's interest in China dated back to the mid-1930s, when his collaboration with a group of Chinese biochemical students - among them Gu Djei-Jen, his lifetime companion and future second wife-awakened his curiosity for this distant land. ${ }^{34}$ With them, and with Gu Djei-Jen in particular, he plunged into the study of China's past, mastered the language, and became an honorary member of the Cambridge Chinese Student Society in 1942. ${ }^{35}$ These exchanges elicited in Needham a voracious interest in China and its scientific traditions - past and present - as well as a concern for its resistance to the Japanese aggression. ${ }^{36}$ Beginning in the mid-1930s, Needham joined a wide array of Anglo-Chinese organizations, such as the Anglo-Chinese Intellectual Cooperation Committee and the Sino-British Cultural Association, which promoted cultural cooperation and mutual understanding. Through these networks, Needham engaged in profuse intellectual exchanges with prominent Chinese scholars (such as Chung Shu Lo) on the potential of Chinese science, as well as on the promising rise of the communists. ${ }^{37}$ By 1939 and the war's outbreak in Europe, Needham was already regularly consulted both in Britain and in China to express his views on China's current political situation, the state of its scientific apparatus, and the potential of tighter East-West cooperation in war. ${ }^{38}$ His reputation as an expert sinophile was ultimately sealed when the British Council, Britain's governmental organization for the promotion of education and British culture abroad, considered Needham as a candidate to conduct a new programme to promote tighter cultural exchanges with China. ${ }^{39}$

With Japan sweeping across Asia and threatening Britain's neighbouring colonies, London and Chongqing felt the pressing need to cooperate against Japan's expansionism. Hence, beginning in 1939, the Anglo-Chinese associations started to campaign for the establishment of greater Sino-British cooperation. These plans stemmed from engaged discussions between Oxbridge and Chinese scholars on the modalities of Sino-British technical cooperation and its underlying political functions for, and beyond, the war. ${ }^{40}$ Within these heated debates, the proposals put forward by Chung

34 Goldsmith, op. cit. (2), pp. 69-70; John B. Gurdon and Barbara Rodbard, 'Biographical memoir on Joseph Needham (1900-1995)', International Journal of Developmental Biology (2000) 44, pp. 9-13.

35 C.Y. Hsich to Joseph Needham, 22 January 1942, NP, Folder C9.

36 Joseph Needham to A.G. Morkill, 18 November 1939, NP, Folder C1.

37 On the correspondence between Needham and Chung Shu Lo see NP, Folders C3 and C39.

38 H.D. Liem to Joseph Needham, 14 March 1941, NP, Folder C7; Poling Chang, Monlin Chiang, Y.C. Mei, Tsee-Chong Van, Liang Chao Cha, Tien-Ting Cheng, Fung Yu-Lan, Y.H. Woo, Su-Ching Chen, ChiaYang Shih and Yu-Sheng Huang to Joseph Needham, 20 April 1941, NP, Folder C7.

39 Chung Shu Lo to the Cambridge Sino-British Cultural Association, 6 May 1941, NP, Folder C7.

40 E.R. Hughes-Joseph Needham correspondence, NP, Folder C5. 
Shu Lo during his 1940 tour in Britain stood out. Through a series of lectures in a dozen British universities, including both Oxford and Cambridge, Lo introduced his British audience to the crippled state of science and education in China and the benefits that an East-West cooperation programme would bring to China's social and scientific development. ${ }^{41}$ Lo's lectures left a strong impression on Needham. The two scholars subsequently established a rich correspondence on the matter of international cooperation throughout the war, which showed its influence on the type of scientific cooperation Needham ultimately envisioned, first between Britain and China, and later at UNESCO.

During his visit to the UK, Lo aimed to convey the immense fascination that Western science exerted upon his colleagues back home. He particularly insisted on their unequivocal faith in the power of Western applied sciences, with which they hoped to alleviate most of the existing hardship in China. Lo ardently believed that greater cooperation with the West would help 'to rejuvenate the nation' and 'raise the general standard of living'. ${ }^{42} \mathrm{He}$ regarded international scientific cooperation as China's best means to overcome the Japanese occupation, elicit societal progress, and revive its scientific tradition. Importantly, Lo also foresaw in these multifarious contacts between East and West the roots of a peace-loving ecumenism. He 'firmly believed that perpetual peace in the world depends on such cooperation between nations, upon understanding and mutual appreciation between the peoples of all races and different types of culture'. ${ }^{43}$ In his view, to advance world peace, scientific cooperation should be a two-way street, a channel through which both ends would benefit from each other's views and ways 'as the common heritage of mankind'. ${ }^{4}$

Needham was particularly receptive to Lo's proposals, which he forcefully defended in Britain. ${ }^{45}$ This support may be explained by the fact that Lo's call for international cooperation resonated with Needham's biological faith in the transformative power of cooperation. In a statement addressed to Chinese scholars in January 1940, Needham placed as much emphasis on the terms of cooperation as on the peace-building promises such a scheme could bring about. ${ }^{46} \mathrm{He}$ argued that in all the interest of human progress, it behoved scholars and scientists of East and West to join more closely than heretofore in correlating their knowledge and traditions' to bring about the necessary unity on which durable peace could be built. ${ }^{47}$ Like Lo, he also expressed concern at cooperation schemes that consisted merely of a cultural influx from Europe and North America. Needham depicted the establishment of a dialogical cooperation as the scientist's

41 Chung Shu Lo, 'Cultural cooperation between China and Britain', 1939, NP, Folder C3; Lo, 'Some ideas for cooperation', 15 November 1939; Lo, 'The past and present of Chinese university education', 4 August 1939; Lo, 'Chinese university education and British universities: a plea for cooperation', nd, NP, Folder C2.

42 Chung Shu Lo, 'A suggestion of cultural cooperation between Cambridge and Chinese university', 8 December 1939, NP, Folder C2.

43 Lo, 'Cultural cooperation between China and Britain', op. cit. (41), p. 4.

44 Lo, 'Some ideas for cooperation', op. cit. (41), p. 2.

45 Chung Shu Lo to Joseph Needham, 4 November 1939, NP, Folder C3.

46 Ernest Barker, F.C. Bartlett, C.D. Broad et al., 'A statement by a group of university teachers in Cambridge addressed to university teachers and other scholars in China concerned with co-operation between British and Chinese universities', January 1940, NP, Folder C4.

47 Barker et al., op. cit. (46), p. 1. 
responsibility, and as the best means to satisfy 'the demand from all corners of the earth for a cessation of disunity'. ${ }^{48}$ The notion of disunity bore a strong evolutionary connotation in Needham's biological outlook. He associated disunity with lower levels of organization that constituted a major impediment to the advancement of a peaceful 'world commonwealth'. Typical of Needham's early Chinese activism, this plea shows the evolutionary foundations that motivated his engagement in favour of East-West scientific cooperation before and during the SBSCO. Hence China appealed to Needham because its state and condition resonated with his bio-Marxist sensitivities. He sensed in China the potential that his particular SRS outlook led him to expect from science.

Needham's statement to Chinese scholars illustrates how Lo had catalysed his British partners. His lectures spurred the local Sino-British circles actively to promote war cooperation with China. The campaign eventually paid off, and British and Chinese authorities subsequently entered negotiation on the matter. ${ }^{49}$ In Britain, Oxford and Cambridge disagreed on the nature of the cooperation with China. Oxford dons, among them G.R. Hughes, privileged cultural cooperation since China was believed to have a stronger, more vivid tradition in philosophy than in the natural sciences, where 'the Chinese did not come alongside western scientists'. ${ }^{50}$ In Cambridge, Needham and his group defended science-centred proposals, in line with Lo's memoranda. Their views finally prevailed in a context where scientific exchanges became a locus of cultural relations. After the outbreak of war, there was a growing demand for scientific information, scientific and engineering equipment, and technical and scholarly expertise among Britain's allies, which was particularly felt by the British Council and its offices abroad. ${ }^{51}$ Facing this demand, the council expanded its activities to include scientific exchanges. Needham's friend, the science journalist and SRS exponent James Gerald Crowther, orchestrated these from 1941 as the secretary of its Science Department. As I will explain in more detail below, this scientific approach to cultural relations was especially important in China, where trading prospects and political importance grew enormously following the Japanese invasion. As Crowther recalled, the council decided in February 1942 to endorse his suggestion to appoint Needham as the leader of its scientific mission, starting the following May. ${ }^{52}$

On the eve of his departure to Chongqing, China was therefore neither a discovery nor a mystery to Needham. For over half a decade, China had increasingly fascinated him. In his Marxist eyes, its future had risen into a political frontier with world significance. Its historical science was an enigma, and its current scientists were competent partners in the promising venture of international scientific cooperation. During his four-year mission, his 1930s world view further nourished his understanding of Chinese science, his

48 Barker et al., op. cit. (46), p. 1.

49 Chung Shu Lo to the Sino-British Cultural Association members of Cambridge concerned with Cooperation between Cambridge University and Chinese Universities, 6 May 1941, NP, Folder C7.

50 G.R. Hughes to Joseph Needham, 6 February 1940, NP, Folder C5.

51 Crowther talked about the creation of the British Council's Science Department and the expansion of its activities during the Second World War in James G. Crowther, Fifty Years with Science, London: Barrie and Jenkins, 1970, pp. 226-232.

52 Crowther, op. cit. (51), pp. 234-235. 
evolutionary outlook helped to shape his views of science as unitary and ecumenical, and his SRS background finally led him to the formulation of his Grand Question.

\section{The Sino-Japanese War and Needham's scientific mission in China}

When Needham arrived in Chongqing in 1943, Republican China had been engaged in a devastating war of resistance against Japan's invasion for the past five years. Between the Marco Polo Bridge incidents of July 1937 that sparked Japan's invasion of China and Needham's arrival, Republican China suffered disastrous losses despite a valiant resistance. Territorially and economically, Republican China had lost its most fertile provinces and the industrially advanced centres of East China. ${ }^{53}$ By 1938, the nationalist government of Chiang Kai-shek was forced to flee to China's barren western regions and to make Chongqing its capital until the end of the war. If, from Chongqing, Chiang ruled over China's largest stretches of land, his government was weakened by the Japanese confiscation of substantial custom revenues drawn from China's eastern trading centres. It was also hampered by the disastrous loss of many of the best nationalist troops in the unsuccessful defence of Shanghai, the former capital Nanjing, and Wuhan. ${ }^{54}$ Even though most foreign observers predicted China's surrender by the end of 1938, Republican China kept on fighting thanks to a united front with Mao Zedong's north-eastern communist troops, Western material assistance from India and the Soviet Union, and the prospect of Western military involvement which Chiang hoped to obtain to defeat the Japanese. ${ }^{55}$

However, for the duration of the war, neither the United States nor Britain considered China a priority as they did Europe and the Pacific. ${ }^{56}$ Yet, if they refused to open up a full-scale campaign on Chinese soil, to Chiang's disappointment, both nations did recognize China's strategic value in slowing down Japanese troops. While, between 1938 and 1941 , the US granted credits of up to $\$ 170$ million to sustain China's war effort, cold relations between London and Chongqing, as well as limited resources, prevented Britain from matching US assistance. ${ }^{57}$ Despite China's heavy reliance on India for resupply, and Churchill's hope to see Japan's expansion towards Britain's South East Asian possessions slowed down by the Chinese front, relations between Chongqing and London remained tense, complicated by Britain's historical status as an imperialist conqueror. From the Opium War to the late 1920s, Britain had been the largest investor in China. However, British presence was almost exclusively commercial as London

53 Rana Mitter, Forgotten Ally: China's World War II, 1937-1945, Boston and New York: Houghton Mifflin Harcourt, 2013, p. 168.

54 Rana Mitter, 'Imperialism, transnationalism, and the reconstruction of post-war China: UNRRA in China, 1944-7', Past and Present (2013), Supplement 8, pp. 51-69, 57.

55 Mitter, op. cit. (53), pp. 182-183.

56 Akira Iriye, 'Japanese aggression and China's international position, 1931-1939', in John K. Fairbank and Albert Feuerwerker (eds.), The Cambridge History of China, vol. 13: Republican China 1912-1913, Part 2, Cambridge: Cambridge University Press, 2008, p. 531.

57 Lloyd E. Eastman, 'Nationalist China during the Sino-Japanese War 1937-1945', in Fairbank and Feuerwerker, op. cit. (56), pp. 576-580. 
granted China little political value. ${ }^{58}$ Britain's brutal presence and humiliating practices fed Chinese Republicans' anti-imperialist and nationalist discourses. A strong resentment of Britain emerged after the anti-imperialist protests of 1919 commonly known as the May Fourth Movement. Chiang's double agenda - seeking Western involvement in the war in China, and strengthening the country as an anti-imperialist model in the region - only further poisoned relations between Chongqing and London. On a visit to New Delhi in 1942 in order to tighten war cooperation between India and China, Chiang infuriated Churchill. ${ }^{59}$ During his time in India, Chiang did more than just discuss with the viceroy the deployment of Indian troops on the Chinese front. He went on to visit the leaders of the Congress Party, Jawaharlal Nehru and Mahatma Gandhi, with whom he discussed war cooperation as well as their shared interest in freeing India and China from Western colonial rule. ${ }^{60}$ Chiang's visit maddened Churchill, who became wary of engaging militarily with a regime feeding anti-British sentiments in India and likely to contest Britain's presence in the Far East once the war was over.

However, Britain's cooperation with China was not just a wartime necessity; it was a strategic issue for the post-war reconstruction of the region. Despite Churchill's mistrust of Chiang's anti-imperialist government, British involvement in the Chinese war effort became unavoidable if Britain's influence on the region was to be maintained after the war. Already weakened by the US-endorsed abolition of foreign concessions in China, following the 1943 Sino-British New Equal Treaty of 11 January 1943, Britain's presence in China and South East Asia was also threatened by growing US influence. ${ }^{61}$ By late 1941, Roosevelt agreed to intensify US support to China's war effort with the Lend-Lease Act, which included provision of \$200 million worth of loans in 1942 only, armaments, military expertise and other war material to Chiang's government. ${ }^{62}$ Seven months later, Washington created the American Military Mission in China (AMMISCA) to improve the fighting efficacy of the Chinese army. Roosevelt also agreed to send troops such as the so-called 'Flying Tigers' of the American Volunteer Group to operate air raids against Japan from Chinese soil. ${ }^{63}$ The US helped Chiang to hamper Japan's expansion as well as to prepare China for a post-war existence as a regional, independent power that could challenge European imperial ambition to reclaim their lost colonies, and in turn strengthen US influence in the region.

Churchill despised the US attempts to raise China's global status - making China one of the Big Four - and feared for Britain's possessions in China, such as Hong Kong, which Roosevelt wanted to see back under Chinese sovereignty. Yet he was concerned to keep China in the war and to slow down Japanese westward advances.

58 Mitter, op. cit. (53), p. 51.

59 Mitter, op. cit. (53), pp. 245-249.

60 Mitter, op. cit. (53), pp. 246-250.

61 Rana Mitter, 'Changed by war: the changing historiography of wartime China and new interpretations of modern Chinese history', Chinese Historical Review (2010) 17, pp. 13-14.

62 Eastman, op. cit. (57), p. 577; Christopher Thorne, Allies of a Kind: The United States, Britain and the War against Japan, 1941-1945, Oxford: Oxford University Press, 1978, pp. 176-177.

63 Mitter, op. cit. (53), p. 251; Eastman, op. cit. (57), pp. 576-577. 
Recognizing the present and future need to improve relations with China, London provided military and financial aid to assist China's war effort.

Still, British aid remained small compared to that of the US. Churchill's material resources had already reached their limits. ${ }^{64}$ Militarily, London only managed to send in January 1942 two small guerrilla groups to China to establish training schools and carry out joint commando raids against the Japanese occupier - but these already had to be withdrawn by the autumn of 1942. Financially, British assistance hovered at around $£ 50$ million worth of loans; the United States came up with $\$ 500$ million between 1942 and 1944.

London's inadequate resources and the popularity of the Chinese cause in Britain forced Churchill to consider other, mostly symbolic, ventures. ${ }^{65}$ Churchill and his Cabinet sought, for instance, to invite Chiang's influential wife Song Meiling to visit Britain. They endorsed Chiang's government with a Parliamentary goodwill mission to Chongqing in 1942 and they publicly honoured Chiang's leadership as well as regularly sending encouraging messages to Chongqing. Among these symbolic measures were also steps to develop cultural and scientific relations. These included the placing of visiting Chinese students in British universities, a visit by Oxford Professor E.R. Dodds to China, and Needham's mission in Chongqing. ${ }^{66}$ Endorsed by the British Council, Needham's scientific mission stood out prominently and would become one of Britain's most conspicuous contributions to the Chinese war effort. ${ }^{67}$

The war had not only interrupted scientific contact between Britain and China; it also disrupted the growth of a thriving scientific community. ${ }^{68}$ Though European science had been present in China since the Opium wars, it experienced significant growth following the anti-imperialist May Fourth Movement of 1919.69 This nationalist protest turned into a far-reaching intellectual revolution, which projected science and democracy in China as instruments to dismantle the country's traditional patterns and to enable modern, independent nationhood. ${ }^{70}$ As shown by Zuoyue Wang, the Science Society of China became a pivotal organization in the promotion of modern science in interwar China. Created by Chinese students in the US, Europe and Japan, the Science Society aimed to implement the expertise gained abroad to conduct China's reformation. ${ }^{71}$ From its creation in 1918, the society worked closely with the Nationalists for the co-

64 Mitter, op. cit. (53), p. 299.

65 Thorne, op. cit. (62), pp. 186-187.

66 Thorne, op. cit. (62), p. 319.

67 Mitter, op. cit. (61), p. 15.

68 James G. Crowther to Joseph Needham, 20 May 1942; the British Council to Joseph Needham, 3 June 1942; Joseph Needham to the British Council, 24 June 1942, NP, Folder C10.

69 On the May Fourth Movement see Rana Mitter, A Bitter Revolution: China's Struggle with the Modern World, Oxford: Oxford University Press, 2004.

70 E-Tu Zen Sun, 'The growth of the academic community, 1912-1949', in Fairbank and Feuerwerker, op. cit. (56), pp. 381-382; Zuoyue Wang, 'Saving China through science: the Science Society of China, scientific nationalism, and civil society in republican China', Osiris (2002) 17, pp. 310-319.

71 Wang, op. cit. (70), pp. 299-306. Wang pointed out that tens of thousands of Chinese came to study in Japan, Europe and the United States. He also referred to a unique survey conducted in 1954 which established that between 1854 and 1954 some 22,000 Chinese had studied in the United States. Zuoye Wang, 'Transnational science during the Cold War: the case of Chinese/American scientists', Isis (2010) 101, 
advancement of modern science and modern politics. During the so-called Nanjing decade (1927-1937) that saw the strengthening of the Chinese republic under the rise to power of Chiang's Kuomintang, the society joined with the government in creating multiple scientific institutions. These included the state-supervised Academia Sinica in 1928 and the National Peiping Research Academy a year later. Thanks to such initiatives Chinese science flourished throughout the 1930s, despite chronic financial shortcomings. As the centralized national scientific research institution, the French-inspired Academia Sinica stimulated the creation of a wide range of research institutes, mainly in natural sciences, such as the Institute of Meteorology in Nanjing and the Institute of Chemistry in Shanghai. In Beijing, the National Research Academy's half-dozen research institutes made valuable contributions until 1936, when political tension with the Japanese occupier in the neighbouring region of Manchuria forced the evacuation of several institutes to safer areas of the south. ${ }^{72}$

The evacuation of the National Peiping Academy pre-empted the fate of China's scientific institutions following the outbreak of war in 1937. The Japanese invasion profoundly affected Chinese science. Located in China's eastern regions, most research institutes were forced to move to safer locations first in the south and later in the west of China, following Japan's conquest of Shanghai in November $1937 .{ }^{73}$ Even though this large-scale operation was completed in the first year of the conflict, it was at the expense of massive material and human losses, including the destruction of twentythree national universities and colleges and the abandonment of valuable equipment in the haste of retreat. Some institutions, like Nankai University, were left in ruins by targeted bombings, while others, such as the Honan University, had, as Needham witnessed, 'not one single scientific or technical book left, all having been burnt by the Japanese on its numerous migrations' ${ }^{74}$ In the west of China, the resupplying of scientific universities was difficult and inadequate despite the government's $\$ 1$ million effort to purchase books and equipment. ${ }^{75}$ Though understaffed, underequipped and isolated, China's evacuated research staff continued to conduct research in basic science and to explore new fields of applied science and technology, such as industrial chemistry, in response to the needs of war. ${ }^{76}$

Shortly after his arrival in Chongqing, Needham modelled the SBSCO into China's main scientific post office, through which he stimulated contact between Chinese and Western scientists and organized material assistance to local scientists. Relying on RAF carriers operating between Calcutta and Chongqing, and aided by a handful of young Chinese scientists, Needham monitored the needs of local scientific communities

pp. 367-377, 369-370; On the survey see Yi Chu Wang, Chinese Intellectuals and the West, 1872-1949, Chapel Hill: University of North Carolina Press, 1966, pp. 119-120, 167, 185.

72 'National Academy of Peiping and its war-time activities', Nature (20 April 1946) 157, p. 524.

73 Sun, op. cit. (70), p. 412.

74 Sun, op. cit. (70), p. 413; Joseph Needham, 'Report II: the second and third year's working of the SinoBritish Science Cooperation Bureau, February 1946', in Needham and Needham, op. cit. (6), pp. 56-75, 59.

75 Sun, op. cit. (70), p. 415.

76 Sun, op. cit. (70), p. 417. 
and delivered them the requested books, laboratory equipment and relevant solutions to their problems when possible.

Needham also visited many of these communities, and during his four-year stay undertook multiple great journeys throughout Free China, from the front line in the neighbourhood of Kunming to the north-western towns of Lanzhou and Dunhuang on the border with the Soviet Union. On these journeys, Needham saw countless universities, industrial plants, research laboratories and arsenals, and talked extensively with scientists about their activities and problems. In Kunming, Needham visited the National South Western Associated University, 'the greatest teaching centre of free China', as well as a multitude of isolated research institutes scattered around Yunnan's capital and only reachable by 'horse-cart, charcoal-burning bus, jeeps or car'. ${ }^{77}$ At the National South Western Associated University, Needham visited the chemical and physics institutes housed in huts built of mud bricks. In these precarious conditions, he witnessed scientists striving to conduct fundamental research on the distribution of cosmic rays and on thermodynamics, as well as more practical investigations on antimalarial drugs and so forth. He noted how the war took a toll on the work, limiting physicists to more theoretical investigations, while 'the lack of chemical reagents seriously hampered the work of the chemical laboratories' ${ }^{78}$

Needham duly recorded these shortcomings and quickly organized the provision of books, tools, apparatus and chemical reagents to enable local scientists 'to carry on their work, whether in pure science or in science applied to the war effort'. ${ }^{79}$ Via the SBSCO's Emergency Scientific Supplies Service, Needham responded to 333 orders from Chinese scientific and technological institutions during his stay. With two war trucks lent by the British Embassy, Needham delivered tubes of gas to the Qinghua University, optical glass to Peiping Academy and electric motors in crates to Chengdu's Chinese Air Force Experiment stations. Importantly, Needham also arranged for the provision of special research services by Western institutes, such as 'the preparation of thin rock sections, chemical analyses, and map printing' which the Chinese could not operate for lack of equipment or expertise. Exchange of expertise was mostly ensured by 'the transmission of selected scientific and technological correspondence' via diplomatic means and, more importantly, by the delivery of thousands of books, periodicals, maps and official government reports. ${ }^{80}$

Needham made a point of keeping Sino-British contact a two-way street. In between visits, Needham and the SBSCO disseminated news about the activities of Chinese scientists to the West via the science newsletter Acta Breva Sinensia, and submitted more than a hundred papers for publication in Western journals and periodicals. Needham also regularly reported on his mission, on China's war and on the state of Chinese science via a series of articles for Nature in 1943 and the photographic book Chinese Science

77 Joseph Needham, 'Article I: science in south-west China. (1) The physico-chemical sciences (1943)', in Needham and Needham, op. cit. (6), pp. 80-81.

78 Needham, op. cit. (77), p. 82.

79 Joseph Needham, 'Report I: the first year's working of the Sino-British Science Cooperation Bureau, February 1944', in Needham and Needham, op. cit. (6), pp. 16-26, 17.

80 Needham, op. cit. (74), pp. 56-57. 
in 1946. Finally, several scientific and state institutions, including the Ministry of Education, the Chinese Air Force Research Bureau and the Academia Sinica, nominated Needham special adviser. Needham was regularly consulted and gave about a hundred lectures on issues as diverse as the 'Conditions and progress of scientific and university life in war-time England', 'Food and nutrition in wartime England', 'University organization' and the philosophy of science. ${ }^{81}$ Despite the demands of his mission as head of the SBSCO, Needham explored his keen interest in China's scientific heritage. He pursued investigations on the origins and nature of modern science, talking with local scholars, visiting ancient sites and lecturing at length on China's scientific history and the history of science between East and West.

\section{Exploring China}

Throughout his mission, Needham's evolutionary outlook continued to inform his firsthand studies of the past and present state of Chinese science. On the road Needham elaborated, from his observations, a narrative of unity and continuity between East and West, past and present science. He soon concluded that 'there was only one international human science', and that his Chinese colleagues were incontestably part of it. ${ }^{82}$ Needham continually rejected the 'ridiculous' idea that 'China had no science' or that the Chinese were inherently unfit for the exigencies of scientific work. ${ }^{83}$ Instead, he celebrated the ingenuity and accomplishments of his Chinese colleagues. He was amazed by 'the scientists and technologists, pertinacious beyond belief, [who] continued to carry on research and operate industrial plants under a lack of facilities which would surely daunt those of any other people'. ${ }^{84}$ In his accounts, Needham not only testified to the quality of their work, but also portrayed the Chinese scientists' resourcefulness as the manifestation of the scientific spirit and method. Even '[w]ithout gas, running water, electric light, or any of the services generally regarded as necessary for scientific work', Needham argued, the Chinese scientists, as true men of science, 'contrived somehow to keep science going, both for its own sake, and for the defence of their country against a specific type of fascism, Japanese imperialism'. ${ }^{85}$ Ultimately, Needham regarded his colleagues 'not as inferior or scientifically backward Orientals, but as full partners with us in the worldwide enterprise of human science and technology'. ${ }^{86}$ With these portrayals, Needham magnified a sense of commonness of cause and equality of standards between both communities. By melding Eastern and Western scientists into

81 Needham, op. cit. (79), p. 23.

82 Joseph Needham, 'Science and agriculture in China and the West (Chungking, 1944)', in Needham and Needham, op. cit. (6), pp. 252-258, 258.

83 Needham, op. cit. (82), p. 255; Joseph Needham, 'Abstract of a lecture on science and civilization in China', 1944, NA, Folder C73.

84 Needham, op. cit. (74), p. 55.

85 Natural Science Division, Guide Booklet: Note of the Section on the Chinese Scientific War Effort and the Work of the Sino-British Science Co-operation Office, International Scientific Exhibition, Paris, 1946, UNESCO Archives, UNESCO Headquarters, Paris (subsequently UA), File UNESCO/Nat. Sci./2, p. 2.

86 Joseph Needham to Percy M. Roxby, February 1946, NA, Folder C98. 
a single ecumenical embodiment of science, Needham ultimately exalted science's unity and universality.

On his journeys, Needham observed the new as attentively as he explored the old China's scientific heritage - to the point where many of his colleagues thought his historical research came at the expense of his actual mission. ${ }^{87}$ Needham searched Chinese history from an evolutionary perspective. In the face of increasing evidence of past technical and theoretical achievements, he sought systematically to find out what, how and when the Chinese had contributed to science's growth, and more importantly why science had stopped progressing in China for so long. As he had predicted in Britain, Needham quickly discovered that ancient Chinese science offered enough fodder to reevaluate the origins of modern science. He eagerly revealed that 'it was the Chinese who first discovered the magnetic compass, gunpowder, paper and printing', which had all been considered European innovations in the growth of modern science. ${ }^{88}$ For Needham, these historical artefacts attested that China was as historically significant as Europe in the development of science. With his findings, Needham began to contemplate modern science as an ecumenical product rather than a strictly European invention.

In seeing science as one, the geographical and historical distance separating its communities would often vanish in Needham's enthusiastic picturing of Chinese science. This was particularly striking in his repeated recording of a curious practice. He noticed that universities and laboratories made a habit of occupying abandoned temples. He recorded, for instance, the case of the Academia Sinica's anthropological institute, which was housed on the rooftop floor of an 'incredible romantic pagoda housing the god of Literature', or that of 'a drug research laboratory housed in an old Buddhist temple'. ${ }^{89}$ When noticing how the pagoda was used, Needham underlined the historical continuity between these ancient spaces and their modern scientific usage, which resonated with the discussions he had had with local scholars on Buddhism and science prior to his visit to the institute. These two cases, where past wonders and present-day achievements were seamlessly intertwined, reflect Needham's tendency to see continuity in science as linear and unitary. China's rich scientific heritage seems also to have reinforced his high opinion of present-day science in China.

Throughout his Chinese peregrinations, Needham composed a narrative of continuity and unity between past and present science as well as between Western and Eastern scientific developments. When repeatedly telling the Chinese, 'Science was your inheritance as much as mine', Needham made science a unifying ecumenism to whose advancement all traditions had continued to contribute. ${ }^{90}$ Yet Needham was not oblivious to China's current difficulties, and as much as he aspired to see a direct link between past and present, he was well aware of the gap that separated Chinese science's former prestige and present rebirth.

87 Huan Hsing-Tsung, 'Peregrinations with Joseph Needham in China, 1943-44', in Li, Zhang and Cao, op. cit. (5), pp. 39-76.

88 Joseph Needham, 'Science and life in wartime China (a broadcast from London, December, 1944)', in Needham and Needham, op. cit. (6), pp. 50-55, 50.

89 Needham, op. cit. (6), pp. 34, 32.

90 Needham, op. cit. (82) p. 258. 
Needham was as astonished by Chinese science's ancient advancement as he was baffled by the stagnation it had experienced over the last centuries. This incongruity led him eventually to formulate his Grand Question. As mentioned earlier, Needham scholars have presented the posing of this question as an epiphanic moment for Needham. As a result, they have largely investigated it in dissociation from his prewar views, conceptions and intentions. However, we have seen that Needham had already extensively studied the social causes behind scientific change prior to his time in China. His historical investigations constituted an integral part of his Marxist outlook, which he maintained once in China. 'If we cannot understand the past', he argued to the Chinese Agricultural Association, 'we have not much hope of controlling the future'.$^{91}$ The same activist approach to historical writing guided the way Needham approached the paradox of Chinese science. At the same time as he strove to uncover the natural and socio-economic factors precipitating the fall of China's ancient science, he would immediately turn these historical insights into a political resource to outline the promising revival of Chinese science.

In trying to explain the mysterious halt of science's growth under the Ming dynasty (1368-1643), Needham turned to the same factors that he had earlier considered in studying the growth of Western science: 'geographical, climatic, social and economic conditions'. ${ }^{92}$ This standpoint was particularly well articulated in the lecture 'Science and agriculture in China and the West' that Needham gave before the Chinese Agricultural Association in Chongqing, in February 1944. This paper addressed China's scientific paradox in relation to the development of its agriculture, and forcefully argued that the rise of what Needham called 'Asiatic bureaucratism', and 'the failure of Capitalism to arise in China ... had something to do with the failure of modern science to arise in China'. ${ }^{93}$ In subsequent years, Needham would generalize this development as the crucial factor for understanding why modern science had grown in the West rather than in China. In Needham's view, China's geography and climate had dulled the growth of maritime life, and prevented the formation of a powerful class of merchants that was necessary for the eventual rise of capitalism. China's social order had produced a powerful bureaucracy that further marginalized the all-important class of merchants. Water scarcity had necessitated China's development of this bureaucratic culture, in order to maintain control over the millions of labourers that were needed to carry out the waterworks that were indispensable for sustaining agriculture. Needham noted that the rise of bureaucratism and the civil servant eventually lessened the need for new forms of knowledge, and hence for science. In Europe, the capitalist spirit of the merchant class had bolstered the need to know 'the properties of matter in inanimate things', in order to sell and buy the products they had brought back from the newly discovered Americas. ${ }^{94}$ This demand for new knowledge in turn paved the way for the growth of the fundamental disciplines of modern science:

91 Needham, op. cit. (82), p. 253.

92 Needham, op. cit. (82), p. 255.

93 Needham, op. cit. (82), pp. 256-257.

94 Needham, op. cit. (82), p. 257. 
physics, chemistry and biology. But none of this had happened in China. Hence, Needham argued, it was 'because of the differences in climatic conditions, in geographical conditions and as a result in social and economic conditions' that China's and Europe's scientific traditions 'had to follow these different courses'..$^{95}$

Needham's lecture on science and agriculture illustrates how deeply his investigations of China were entrenched in his scientific Marxism. Just as he had done for Western science, Needham pointed to the feudal context rather than the inherent features of Chinese science to grasp both its past glory and its enigmatic failure to elicit a scientific revolution. For Needham, Chinese science failed to transform from traditional to modern not because it lacked the qualities to bring about such a change, nor because it was somehow simply inherently different from Western science. It did so only because of its entanglement with feudal bureaucratism; this was what made science become specifically Chinese. Hence Needham explained science's diversity in light of its social and material contexts alone. Chinese and European science existed separately due to their contextual differences rather than because of inherent differences of an epistemological or ontological nature. Needham did not believe science to be qualitatively different in different cultures. Only its level of development depended on cultures, not its contents.

In concluding his lecture, Needham reasserted this faith in science's unity when he proclaimed that 'there was no such thing as "foreign" or "Chinese" science' in absolute terms. ${ }^{96}$ Science was a uniquely universal endeavour whose diversity only arose once the context of its undertaking was considered - just the same consideration he had given in his investigations of the 1930s. Just as he had then regarded science as becoming Nazi (and therefore degenerated) as it was subordinated to irrational racialist theories, Needham now saw science as becoming Chinese (and vegetative) from the moment when bureaucratic order tamed its vitality. To understand the decline of Chinese science, Needham therefore adopted the same scientific Marxism that he had used to differentiate capitalist, Nazi and communist science back in Cambridge.

The Marxist roots of Needham's Grand Question are particularly striking in his use of the concept of Asiatic bureaucratism. ${ }^{97}$ The German historian Karl Wittfogel had elaborated this notion in the 1920s, based on Marx and Engels's notion of an Asiatic mode of production. ${ }^{98}$ Needham used both the notion of Asiatic bureaucratism and that of an Asiatic mode of production to explain the failure of Chinese science. ${ }^{99}$ It is true that these notions had been condemned by the Marxist orthodoxy since the early

95 Needham, op. cit. (82), p. 257.

96 Needham, op. cit. (82), p. 258.

97 Needham used the notion of Asiatic bureaucratism for the first time in Needham, op. cit. (82), p. 258; he later reflected on it upon his return to Britain in Joseph Needham, 'On science and social change', Science and Society (1946) 10, pp. 225-251.

98 See Karl Wittfogel, Wirtschaft und Gesellschaft Chinas: Versuch der wissenschaftlichen Analyse einer großen asiatischen Agrargesellschaft, Leipzig: Hirschfeld, 1931.

99 On the concept of Asiatic mode of production see Stephen P. Dunn, The Fall and Rise of the Asiatic Mode of Production, Oford: Routledge \& Keagan Paul Ltd, 1982; see also Brook, op. cit. (11), p. 344. 
1930s. ${ }^{100}$ As Gregory Blue has pointed out, Stalin himself had orchestrated the rejection of the notion of an Asiatic mode of production from the canon of Marxism at a crucial Soviet conference on oriental studies held in Leningrad in 1931. ${ }^{101}$ This had led many Marxist scholars, including Wittfogel, to abandon it. What this shows, however, is how distant scientists like Needham were from the official Soviet orthodoxy. As Gary Werskey has shown, Britain's 'scientific left' had remained relatively untouched by Marxism throughout the 1920s and was therefore spared the Soviet grip that held Marxist theory in continental Europe in the 1930s. ${ }^{102}$ Needham himself did not even join the British Communist Party as his friend Bernal did. But his distance from orthodoxy did not imply a rejection of Marxist historical interpretation, and his use of the notions of an Asiatic mode of production and Asiatic bureaucratism does testify to a Marxist historiographical framework, however dissenting or heterodox.

Needham always concluded his reports on the history of China's science by laying down the path forward, arguing that socialism, and implicitly the advancement towards superior organizational orders, could elicit a much-awaited rebirth of the country's scientific tradition. ${ }^{103}$ In investigating China's past, Needham continuously engaged with its present and future, reflecting his long-standing tendency to weld scholarship and Marxist politics. Needham's forward-looking propensity had featured in his historical investigations since the early 1930s, and similarly impregnated the formulation of his concept of ecumenical science. As we will see in the following section, Needham conceptualized ecumenical science not only as a historiographical instrument, but also as the foundation of his political engagement at UNESCO for a reorganization of post-war international science.

Needham scholars have almost exclusively remembered Needham's concept of ecumenical science as a historiographical notion. But it also bears a distinct and crucial political thrust that becomes visible once its formulation is considered in relation to his promotion of science at UNESCO. Originally, Needham travelled in China not to investigate its past scientific glory, but to organize contact between British and Chinese scientists. The seclusion of China's scientific communities reinforced Needham's belief that without an adequate organization and the infrastructural means to facilitate international contact, science's universalism would remain illusory. Through the arduous task of establishing East-West contact, he became convinced that science needed a large-scale reorganization on the international level to liberate its universal features. Much of Needham's activism on this subject went back to December 1943, when he corresponded with T.V. Sung, the Chinese minister of foreign affairs at the time. ${ }^{104}$ 'The

100 Robert Finlay, 'China, the West, and world history in Joseph Needham's "Science and Civilisation in China”', Journal of World History (2000) 11, pp. 265-303, 274-275; Brook, op. cit. (11), pp. 344-345.

101 Blue, op. cit. (14), pp. 204-206, also described the nature of the disputes that divided Marxist thinkers regarding China's status before Stalin expelled the notion of Asiatic mode of production from the official Soviet historiography.

102 Werskey, op. cit. (17), pp. 179-185.

103 Joseph Needham, 'International science cooperation in war and peace', 1943, NA, Folder C72.

104 Joseph Needham, 'Science and international relations', fifteenth Robert Boyle Lecture, Oxford University Junior Scientific Club, 1 June 1948, NA, Folder G70, p. 5. 
time has gone when enough can be done by scientists working as individuals. What I should like to see', Needham wrote to Sung, 'is some kind of World Science Cooperation Service [whose] immediate aims ... would be the conveyance of the most advanced applied and pure science from the highly industrialized western countries to the less highly industrialised eastern ones', with, he insisted, 'plenty of scope for traffic in the opposite direction too'. ${ }^{105}$ Needham further elaborated this need, which he called the 'periphery principle', in his first 'Memorandum on an international co-operation service' in the summer of $1944 .{ }^{106}$ From then and until the decisive negotiations at the 1945 Conference for the Establishment of the United Nations Educational, Scientific and Cultural Organization, Needham published three widely distributed memoranda to advocate such an ecumenical reorganization of international science under UN auspices. ${ }^{107}$ In this final section, we will see that the concept of scientific ecumenism served to strengthen this plea and to legitimize the mobilization of international science for UNESCO's peace-building purposes. Hence seeing Needham's scientific ecumenism in relation to the periphery principle reveals its political as well as its historiographical functions.

Needham's proposal to include science in UNESCO epitomized the growing politicization of science in the late 1940s. The Second World War inaugurated a new scientific era by placing technoscientific development at the heart of the political process, both at the national and international levels. ${ }^{108}$ As John Krige and Kei-Henrik Barth pointed out, nation states and international organizations alike made science an inherent part of the post-war political and diplomatic process. ${ }^{109}$ Based on the ties established between science and the war effort, industrialized and industrializing nations sought to turn scientists and their expertise into strategic assets vital to their growth and continuity as much as to their diplomatic power and political solidity. ${ }^{110}$ At the international level, many like Needham found in the emerging United Nations a space to mobilize science for the promotion of peace. When Needham obtained the creation of a Natural Science division at UNESCO in 1946, the French physiologist and deputy secretary general of the UN Henri Laugier advocated at the United Nations Economic and Social Council (ECOSOC) the creation of UN-sponsored international laboratories. Meanwhile the UN Security Council led negotiations on the peaceful development of atomic energy

105 Joseph Needham to T.V. Sung, 29 December 1943, NA, Folder D1.

106 Joseph Needham, 'First memorandum on an international science cooperation service (Chungking, July, 1944)', in Needham and Needham, op. cit. (6), pp. 274-282.

107 Needham, op. cit. (106); Joseph Needham, 'Memorandum addressed to the Parliamentary and Scientific Committee - measures for the organization of international cooperation in science in the postwar period', December 1944, NA, Folder D6; Joseph Needham, 'The place of science and international scientific cooperation in postwar world organization, Memorandum III', 28 April 1945, NA, Folder D14.

108 David Edgerton, Britain's War Machine: Weapons, Resources and Experts in the Second World War, London: Allen Lane, 2011; Edgerton, Warfare State: Britain 1920-1970, Cambridge: Cambridge University Press, 2005.

109 John Krige and Kai-Henrik Barth, 'Science, technology, and international affairs', Osiris (2006) 21, pp. $1-21$.

110 John Krige and Jessica Wang, 'Nation, knowledge and imagined futures: Science, technology and nation-building, post-1945, History and Technology (2015) 31, pp. 171-179; see also Naomi Oreskes and John Krige, Science and Technology in the Global Cold War, Cambridge, MA: The MIT Press, 2014. 
and the Food and Agriculture Organization (FAO) and World Health Organization (WHO) turned to scientific and technological research to tackle reconstruction, hunger and overpopulation issues. ${ }^{111}$

The war and its termination hence offered Needham a unique opportunity finally to implement his vision of science as a powerful machinery for progressive and peaceful social change, a vision which he had theorized and promoted since the early 1930 s. Needham believed that science could shepherd humankind to a higher and more harmonious organizational order, because it emulated nature's cooperative mechanics of evolution. ${ }^{112}$ When finalizing his first memorandum, Needham continued to foresee the dawn of peace in cooperation. He proposed science as the ideal candidate to foster the post-war peace that the architects of the UN sought to establish. Reflecting on UNESCO's peace mission, he declared in his 1948 Boyle lecture that UNESCO's 'most obvious way to carry out its purpose for peace was to encourage all those ways in which people from many countries meet together to do a concrete job of work'. Needham continued by arguing that 'there was no field which had a stronger tradition of international community work than that of the natural sciences, and it could indeed be taken as a model'. ${ }^{113}$ Since scientists were 'world-minded' and science was 'essentially and traditionally international and cooperative', Needham made it clear at UNESCO's preparatory commission that the scientist could well be UNESCO's best agent for the promotion of world peace. ${ }^{114}$ It might then appear that Needham embraced a traditional form of scientific internationalism based on the so-called

111 Patrick Petitjean, 'Finding a footing: the sciences within the United Nations system', in Patrick Petitjean, Vladimir Zharov, Gisbert Glaser, Jacques Richardson, Bruno de Padirac and Gail Archibald (eds.), Sixty Years of Science at UNESCO 1945-2005, Paris: UNESCO publishing, 2006, pp. 48-52; Petitjean, 'Giving science for peace a chance: the post-war international laboratory projects', in ibid., pp. 52-57; Aant Elzinga, 'UNESCO and the politics of international cooperation in the realm of science', in Patrick Petitjean (ed.), Les sciences coloniales: Figures et institutions, Paris: Orstom édition, 1996, pp. 163-202; Aant Elzinga and Catharina Landström, Internationalism and Science, London: Taylor Graham, 1996. On the FAO see Amy L.S. Staples, 'To win the peace: the Food and Agriculture Organization, Sir John Boyd Orr, and the World Food Board proposals', Peace and Change (2003) 28, pp. 495-523.

112 Needham followed a long tradition of scientific universalism and internationalism. With his ISCS, he reproduced the commonly held idea that because of science's inherent universality, scientists were united through a single global pursuit and thus formed as a community a model of peaceful cooperation. For a historical overview of the shifting conceptions of science's internationality see Geert J. Somsen, 'A history of universalism: Conceptions of the internationality of science from the Enlightenment to the Cold War', Minerva (2008) 46, pp. 361-379. For more studies on how scientific internationalism has been differently conceived in interwar Europe see Brigitte Schröder-Gudehus, Les scientifiques et la paix: La Communauté Scientifique Internationale au cours des années 20, Montréal: Les Presses de l'Université de Montréal, 1978; Paul Forman, 'Scientific internationalism and the Weimar physicists: The ideology and its manipulation in Germany after World War I', Isis (1973) 64, pp. 150-180; Sven Widmalm, 'Science and neutrality: the Nobel Prizes of 1919 and scientific internationalism in Sweden', Minerva (1995) 33, pp. 339-360; Waqar H. Zaidi, 'Technology and the reconstruction of international relations: liberal internationalist proposals for the internationalisation of aviation and the international control of atomic energy in Britain, USA and France, 1920-1950', PhD thesis, Imperial College London, 2008.

113 Needham, op. cit. (104), p. 6.

114 Preparatory Commission, 'Revised progress report on the programme of the UNESCO. Chapter V. Natural Sciences, 11 September 1946, UA, file UNESCO C/2, p. 1; Preparatory Commission, 'Progress report on the programme of the UNESCO', 1946, UA, File UNESCO/Prep.Com./51, p. III. B. 
functionalist idea of an erosion of national allegiances through transnational loyalties among technical groups. However, reducing Needham's internationalism to mere functionalism would ignore its ecumenical foundations.

While developing his fascination for China's past and present, Needham started to envision science as an ecumenical human endeavour. Science grew over a long period of time and 'was the result of co-operation between men and the accumulation from one age to another'. It was clear that 'the peoples of the whole world have all made their contributions'. ${ }^{115}$ Through its ecumenism, science had a unique unifying power. In investigating science's historical development, Needham saw Eastern and Western cultures in dialogue contributing together to human progress. Needham openly questioned the use of expressions such as 'foreign' or 'Western' science and contended instead that 'there is only one international human science - it is our common possession'. ${ }^{116}$ Importantly, the ecumenism that engendered modern science was not only a thing of the past. Needham foresaw new scientific and political opportunities in its revival. If ecumenical exchanges between Eastern and Western scientific traditions had spawned modern science, Needham trusted it would bring about its future advancement as well. Hence the revival of science's ecumenism would be the pathway towards the 'inauguration of one whole collective society'. 'If we make further efforts in this direction', Needham claimed to the staff and students of West China Union University in Hua $\mathrm{Ta}$, 'the age of "All within the four seas are one family" will not be far distant'. ${ }^{117}$ In the torment of war, but with its end in sight, Needham stated that a truly international science would be 'the forecast of the world of tomorrow, as well as the inheritance of scientists the world over'. ${ }^{118}$ The problem, which Needham would attempt to tackle months later at UNESCO, was to turn international science from a Western to an ecumenical structure.

In his three memoranda, Needham turned his ecumenical view of science into both a critique of the existing laissez-faire organization and a non-Eurocentric plan for the reorganization of international science in the service of peace. While the Conference of Allied Ministers of Education (CAME), the constitutional antechamber of the future UNESCO, had focused on the post-war reconstruction of science in Europe, Needham set the goals of a reorganization of international science outside the West. Needham postulated that science's natural internationalism could only be effective if science was first truly universal in practice. However, he had observed in China many isolated communities of scientists, which appeared to him as demonstrations of the limits of science's universality. From these experiences, Needham came to see

115 Joseph Needham, 'Science and society by a Chinese student reporter', in Needham and Needham, op. cit. (6), pp. 120-121, 120.

116 Needham, op. cit. (82), p. 257. This statement reflects Needham's ambiguous conception of science's universality. Needham never questioned science's universality but criticized its existing organization for hampering its universal outreach. For him, science's intrinsic universalism would finally become a tangible reality once the world's scientists were organized in a tight and cooperative community. When, and only when, connected, for instance via the International Cooperation Service that he wanted UNESCO to implement, science would become one.

117 Needham, op. cit. (115), p. 121.

118 Needham, op. cit. (115), p. 121. 
international contacts and cooperation in science as complex organizational challenges rather than self-evident consequences seamlessly unfolding from the practice of science. He rejected what he called the 'laissez-faire' organization of science, or 'this parochial theory ... that in science everyone knows everyone else, and can, therefore, easily get in touch when any problem arises which calls for it'. ${ }^{119}$ Needham argued that 'the "laissez-faire" dons [who] look at the scene too exclusively from the Euro-American point of view, [and who] think of oscillating between Paris, Brussels, London, New York ... do not realize that the picture of world science looks very different when seen from Romania, Peru, Java, Siam or China'. ${ }^{120}$ So far, international exchanges had been mostly confined to what Needham called the "Bright Zone" covering Europe and North America where all the sciences were relatively advanced'. Now it was time to expand scientific cooperation to the 'Dark Zone' of the rest of the world. ${ }^{121}$

One main vehicle for achieving this goal was to be the International Science Cooperation Service (ISCS) that Needham had first proposed to Minister Sung. Its chief challenge consisted in the durable organization of Eastern science and East-West scientific contacts. Needham made clear that the ISCS's mission was to 'not interfere too much within the "bright zone" and to assist particularly the scientists and technologists in the far regions of the world outside the bright zone who', he believed, 'needed the helping hand of international science' ${ }^{122}$ By tackling the imbalanced development of science, the ISCS would overcome the 'inevitable national loyalty' and fundamentally Western emphasis of the existing structures of international science such as international congresses and unions. ${ }^{123}$ The ISCS could consequently make supranational loyalty possible and enable the full expression of science's peace-making qualities since, through it, scientists from China to Britain would work together to broaden the pool of knowledge, and would thereby extend the capacities of science to serve humankind's most pressing needs. The spirit of Needham's ecumenical view ended up pervading the policy proposals that the preparatory commission - summoned by the constituent conference to discuss and define UNESCO's mandate and programme-submitted to UNESCO's first General Conference in September 1946. In the report of its natural science subcommittee, Needham and his colleagues hence declared that 'to ensure a lasting peace, steps such as the ISCS - must be taken to smooth out as quickly as possible the quantitative differences in "scientific density" which now exist between different regions, and thus minimise, if not remove, the tensions which invariably lead to war.' ${ }^{24}$ In December 1946, the General Conference not only approved Needham's proposals but also appointed Needham director of UNESCO's natural science division. In the two years

119 Needham, 'The place of science ...', op. cit. (107), p. 3.

120 Needham, 'The place of science ...', op. cit. (107), p. 3.

121 Needham, 'The place of science ...', op. cit. (107), p. 3.

122 Needham, 'The place of science ...', op. cit. (107), p. 3.

123 Needham, 'The place of science ...', op. cit. (107), p. 2.

124 Needham acted as special counsellor to the natural-science subcommittee of the Preparatory Commission. UNESCO Preparatory Commission, 'Revised progress report on the programme of the United Nations Educational Scientific and Cultural Organisation, Chapter V, natural sciences’, 11 September 1946, UA, File UNESCO C/2, p. 3. 
he remained in function he would try to realize his ecumenical vision. He organized multiple major international conferences outside the West (in Uruguay, Peru and Chile, among other places). ${ }^{125} \mathrm{He}$ established 'field science cooperation offices' in Latin America and in East and South Asia for the purpose of strengthening contacts between the scientists here and in the main centres of research of the West. And he planned to establish international laboratories in all corners of the 'Dark Zone', such as the International Institute for the Hylean Amazon (IIHA) in 1947.126 For Needham all these activities were part of the grand task of building ecumenism in science.

\section{Conclusion}

Needham scholars have spoken of a first and second half-life to describe his rich existence and have made his encounter with China the divider between these two 'half-lives'. The investigation of Needham's Chinese experience offered here does not contest the fact that his career switched from biochemistry to the history of science upon his return from China. Yet some essential qualifications can be made as to how that shift came about.

First, the division of Needham's life into two has separated his interest in China almost totally from his first half-life. But as we have seen, his militant engagement in the SRS movement and his evolutionary Marxist view of science's development underpinned his interpretation of ancient Chinese science as well as the formulation of his Grand Question. If exploring China brought Needham to embrace history as a profession after the Second World War, this transition occurred in continuity with an existing interest in the development of science that he had extensively explored throughout the 1930s.

Second, the present and future potential of Chinese science captivated Needham as much as did its past heritage. Just as he had explored Britain's scientific history, Needham studied and publicly shared his conclusions on the possible sources of China's scientific and social revival. By restoring the grandeur of China's past achievements and attributing its fall to external factors, Needham debunked the idea that the 'oriental' was condemned to scientific and social inferiority. Quite the contrary: the context was the problem, not the scientists themselves. Needham granted China a place in the realm of science as a major initiator, claiming that with adequate social and political support 'China [might] become in twenty years or so a leading scientific nation'. ${ }^{127}$ Needham's narratives had a clear emancipatory dimension for his Chinese colleagues. Many were reinvigorated by the promise his outlook brought about, and appreciated, as Fu Ssu-nien did, that 'instead of seeing our poverty and simplicity he saw our perseverance, instead of our backwardness, our future hopes', and that moreover he aroused 'a new appreciation of China' in the West. ${ }^{128}$ Even though Western

125 Needham's natural-science division organized the Latin American Conference for the Development of Science (LACDOS) in Montevideo, Uruguay; the High Altitude Biology Conference in Lima, Peru; and the first Latin American Marine Biology Congress at Vina del Mar, Chile.

126 'UNESCO's main activities in the western hemisphere: memorandum presented to the first meeting of the Inter-American Cultural Council', 1951, UA, File WS/081.145, p. 16.

127 Needham, op. cit. (88), p. 54.

128 Fu Ssu-nien, 'Farewell by Fu Ssu-nien', in Needham and Needham, op. cit. (6), pp. 285-286, 286. 
science shone brighter for its achievements and advancements, it was the latecomers, such as China, that Needham came to esteem as the new political and scientific frontier of the post-war world. Needham envisioned science as a global endeavour in which China, for its past heritage and wartime rebirth, was a member as irreducible and legitimate as the West. With his ecumenical outlook on science, Needham valued the reawakening of science's Eastern tradition as a necessary step towards the dawn of a fully universal science and a peaceful commonwealth of humanity.

Finally, rediscovering Needham's ecumenism in context allows us to see how his historiographical toolbox - that is, the concepts of ecumenical and unitary science emerged as an essential dimension of his anti-Eurocentric politics of science. Both his work in Sino-British cooperation and his militancy for a reform of international science through the ISCS and UNESCO turned out to be integral parts of his conceptualization of science as unitary and ecumenical. Recontextualizing Needham's concept of scientific ecumenism has thus allowed us to appreciate its inherent politics. China was more than just a scholarly wonder for Needham. It also became a political turning point. It allowed his concept of ecumenism not only to precipitate his shift from biochemistry to the history of science, but also to remodel his revolutionary militancy of the 1930s into the form of evolutionary scientific internationalism that he first advocated through his engagement at UNESCO. 